\title{
Application of Cross-Plotting Techniques for Delineation of Coal and Non-Coal Litho-Units from Well Logs in Jharia Coalfield, India
}

\author{
Rima Chatterjee, Suman Paul \\ Department of Applied Geophysics, Indian School of Mines, Dhanbad, India \\ Email: rima_c_99@yahoo.com
}

Received September 5, 2012; revised October 10, 2012; accepted October 20, 2012

\begin{abstract}
Well log responses can be used to delineate coal and carbonaceous shale from other non-potential litho-units by cross-plotting technique. The cross-plotting between gamma ray and density had been carried out for 15 wells of Jharia coalfield, India. Through these different cross-plots across the study area, different litho-units like; coal, shaly coal, carbonaceous shale, shale, sand/sandstone, shaly sand, jhama and igneous intrusion (mica peridotite) have been identified. Clustering of points for different lithologies in the above cross-plots indicate that the different trends with marginal overlap between carbonaceous shale/shaly coal and shale as well as shaly sand and shale. The coal horizons are mostly overlain and underlain by shale or sandstone. Cross-plot analysis indicates the various coal lithologies which will play important role in CBM exploration and exploitation strategy.
\end{abstract}

Keywords: Jharia Coalfield; Cross-Plot; P-Wave Impedance; CBM Reservoir

\section{Introduction}

Well log responses can be used to delineate coal and carbonaceous shale from other non-potential litho-units by cross-plotting technique. Identification of lithologies above and below coal seams is important to know the variation in permeability, velocity and elastic properties of rocks immediately overlying and underlying CBM reservoir for identification of the best targets for CBM exploration and production [1-5].

Cross-plotting or statistical techniques enable evaluation of lithology and pore fluid variations on both regional and detailed reservoir scale [6,7]. Anderson and Gray [8] as well as Gray and Andersen [9] had demonstrated that many different lithologies like coal, shale, sandstone, gas saturated sands and carbonates can be identified by cross-plots of $\lambda \rho$ versus $\mu \rho$ (where $\lambda$ is elastic parameter, $\mu$ is rigidity modulus and $\rho$ is density).

The elastic properties, suh as velocity, density and impedance are of critical importance in characterization of CBM reservoir unconventional gas play $[10,11]$. The main objective of this paper are to identify of litho-units of coal bearing formation by cross-plotting technique between physical properties of formation such as: gamma ray versus density, gamma ray versus resistivity, gamma ray versus $\mathrm{P}$-wave velocity and gamma ray versus Pwave acoustic impedance and to identify and classify major coal seams with the help of available well logs, litho-logs and coal core samples.

\section{Study Area}

Present study area, consisting of Singra, Kapuria, Barki and Jarma blocks is located in the south-central part of Jharia coalfield (Figure 1). Table 1 is showing generalised stratigraphic sequence of Jharia coalfield, India [12]. Available well logs, litho-logs and core samples of total 15 exploratory wells have been considered for present study. Figure 1 displays locations of 15 exploratory wells in the study area.

Out of the 15 exploratory wells, wells S1, S5, S8, S10 and S14 are located in Singra block; wells K1, K4, K8, $\mathrm{K} 10$ and J2 are located in Kapuria block; wells J1, J3 and $\mathrm{J} 4$ are located in Barki block and wells M1 and M2 are located in Jarma block (Extension of Moonidih block) of Jharia coalfield (Figure 1).

\section{Identification of Litho-Units from Cross-Plots of Well Logs}

A common practice in log interpretation is to cross-plot various porosity log readings in order to determine formation lithology and accurate porosity. The neutron logs and gamma ray logs complement each other and are often used together. The natural gamma ray log tends to respond to changes in clay mineral content, while the 


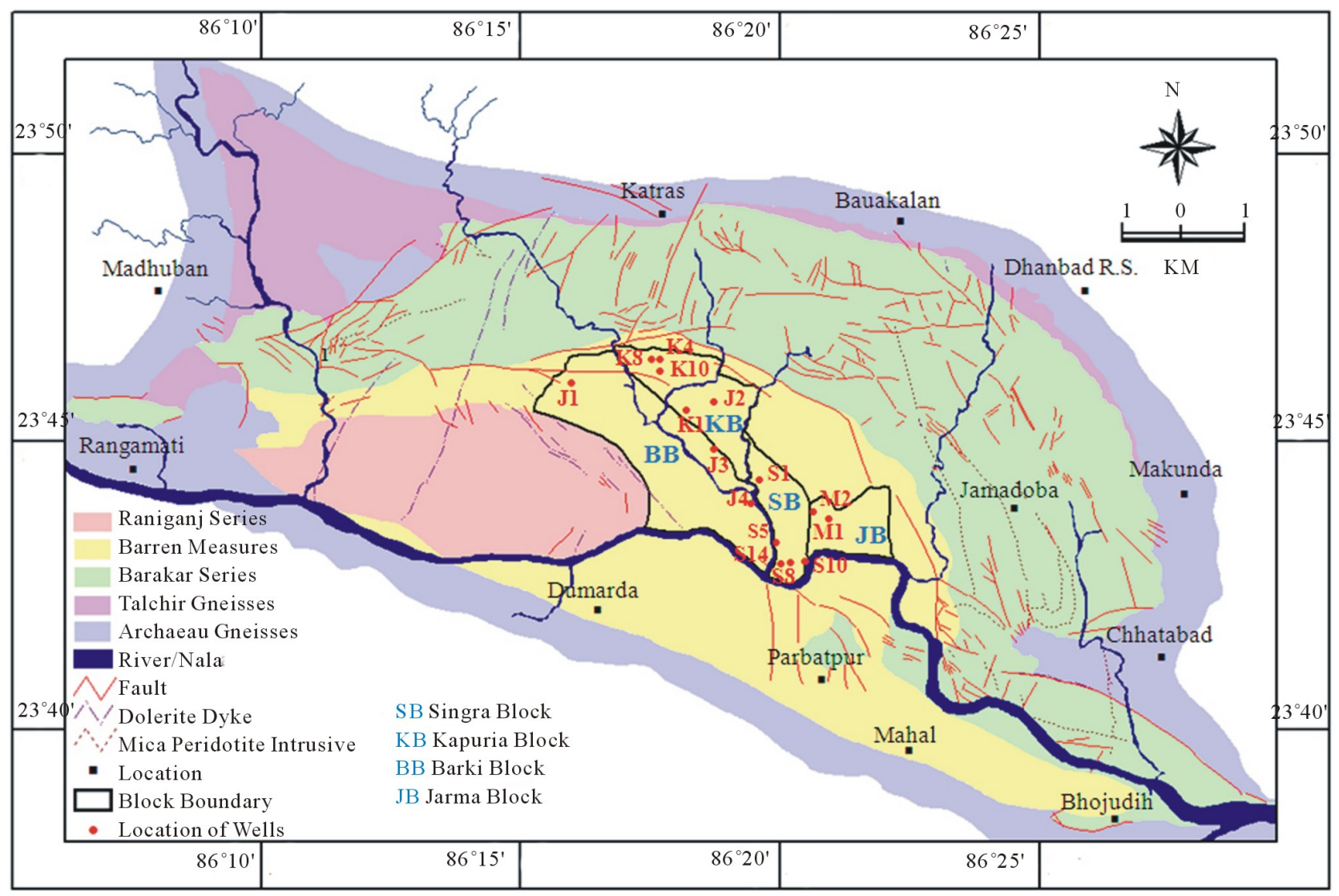

Figure 1. Structural and stratigraphic map of Jharia coalfield, India (after Sengupta, 1980). Showing locations of 15 numbers of exploratory wells distributed in Singra, Kapuria, Jarma and Barki blocks of Jharia coalfield, India.

Table 1. Generalised stratigraphic sequence of Jharia Coalfield, India.

\begin{tabular}{|c|c|c|c|c|}
\hline Age & Group & Formation & Litho-Type & $\begin{array}{l}\text { Maximum } \\
\text { Thickness }\end{array}$ \\
\hline $\begin{array}{l}\text { Recent \& } \\
\text { Sub-Recent }\end{array}$ & & Weathered & Alluvium, sandy soil, clay, gravel etc. & $30 \mathrm{~m}$ \\
\hline Jurassic & & $\begin{array}{l}\text { Deccan Trap \& Other } \\
\text { Igneous } \\
\text { Intrusives }\end{array}$ & Dolerite dykes, Mica lamprophyre dyke \& sills & \\
\hline Upper Permian & & Raniganj & $\begin{array}{l}\text { Fine grained feldspathic sandstones, shales with coal } \\
\text { seam }\end{array}$ & $800 \mathrm{~m}$ \\
\hline Middle Permian & $\begin{array}{l}\text { D } \\
\text { A } \\
\text { M }\end{array}$ & Barren Measure & $\begin{array}{l}\text { Buff coloured sandstone, shales and carboneceous } \\
\text { shales }\end{array}$ & $730 \mathrm{~m}$ \\
\hline Lower Permian & $\begin{array}{l}\mathrm{U} \\
\mathrm{D} \\
\mathrm{A}\end{array}$ & Barakar & $\begin{array}{l}\text { Buff coloured coarse to medium grained feldspathic } \\
\text { sandstones, grits, shales, carboneceous shales and } \\
\text { coal seam }\end{array}$ & $+1250 \mathrm{~m}$ \\
\hline Upper Carboniferous & & Talchir & Greenish shale and fine grained sandstones & $245 \mathrm{~m}$ \\
\hline Archaeans & & & Metamorphics & \\
\hline
\end{tabular}


neutron log tends to respond to changes in porosity. Coal can be identified on neutron logs because it is rich in hydrogen and thus produces a very good porosity (very low count rate). Gamma ray logs show clear differences between carbonaceous shales and coal, which are poorly distinguished on neutron logs. Contacts between coal and clean sandstones, on the other hand are clear on neutron logs but difficult to distinguish on gamma ray logs. Neutron and other logs have been compared to identify the lithology of inter-seam strata. Carbonaceous shale is identified by high gamma ray response and low density values from low density coal [13].

In coal beds identification, the special acoustic properties of the coal formation, e.g., low velocity and low density, cause large impedance contrasts between coal seams and inter-seam sediments and is to be reflected in the gamma ray versus impedance cross-plots. Neutron logs are not useful for identification of waterfilled plies of coal seams. More information can be obtained by comparing two logs than by using each log independently, so cross-plotting technique are used to quantitatively compare different logs of a given stratum.

Gamma ray, resistivity, density, sonic and neutron log data were available only for five wells (J1, J3 and J4). The most common logs like gamma ray, density and caliper log data were available for 15 wells (S1, S5, S8, S10, S14, K1, K4, K8, K1, J1, J2, J3, J4, M1 and M2).

The physical parameters like density, resistivity, Pwave velocity, P-wave impedance and neutron porosity have been plotted with gamma ray to identify different litho-units like coal, shaly coal, shaly sand and sand for the three wells, namely: J1, J3 and J4. The cross-plotting between gamma ray and density had been carried out for 15 wells. Through these different cross-plots across the study area, different litho-units like: coal, shaly coal, carbonaceous shale, shale, sand/sandstone, shaly sand, jhama and igneous intrusion (mica peridotite) have been identified. Table 2 indicates the range of values of physical parameters for each litho-unit estimated from well logs of 15 exploratory wells in Jharia coalfield.

\section{Cross-Plot Analysis}

Results of different cross-plot analysis have been discussed for 10 wells, such as: J1, J2, J3, J4, S1, S10, S14, K4, K10 and M1. The physical parameters like density, resistivity, $\mathrm{P}$-wave velocity and $\mathrm{P}$-wave impedance have been plotted with gamma ray for well $\mathrm{J} 1$ for a selected depth interval of $249.92 \mathrm{~m}$ to $1052.62 \mathrm{~m}$ (Figure 2). The clustering of points could discriminate coal and mixed litho-units like coal and shaly coal as well as shaly sand from the gamma ray versus density, gamma ray versus resistivity, gamma ray versus $\mathrm{P}$-wave velocity and gamma ray versus $\mathrm{P}$-wave impedance cross-plots. Coal in this horizon in well $\mathrm{J} 1$ is characterized by low gamma ray value (less than $40 \mathrm{cps}$ ), density ranging from $1.28 \mathrm{gm} / \mathrm{cc}$ to $1.55 \mathrm{gm} / \mathrm{cc}$, resistivity ranging from $800 \mathrm{ohm}-\mathrm{m}$ to 2800 ohm-m, P-wave velocity ranging from $2400 \mathrm{~m} / \mathrm{sec}$ to 3000 $\mathrm{m} / \mathrm{sec}$ and P-wave impedance ranging from 3500 $\mathrm{gm} / \mathrm{cc}^{*} \mathrm{~m} / \mathrm{sec}$ to $4500 \mathrm{gm} / \mathrm{cc}^{*} \mathrm{~m} / \mathrm{sec}$. Shaly coal is characterized by density $1.6 \mathrm{gm} / \mathrm{cc}$ to $1.8 \mathrm{gm} / \mathrm{cc}$ with resistivity $300 \mathrm{ohm}-\mathrm{m}$ to $700 \mathrm{ohm}-\mathrm{m}$, velocity $3500 \mathrm{~m} / \mathrm{sec}$ to $4000 \mathrm{~m} / \mathrm{sec}$ and impedance $6000 \mathrm{gm} / \mathrm{cc}^{*} \mathrm{~m} / \mathrm{sec}$ to 8000 $\mathrm{gm} / \mathrm{cc}^{*} \mathrm{~m} / \mathrm{sec}$. Shaly sand is distinguishable by lowering of resistivity value about 80 ohm-m to 100 ohm-m, gamma ray of $50 \mathrm{cps}$, P-wave velocity of $4000 \mathrm{~m} / \mathrm{sec}$ to $5000 \mathrm{~m} / \mathrm{sec}$ and P-wave impedance of $7800 \mathrm{gm} / \mathrm{cc}^{*} \mathrm{~m} / \mathrm{sec}$ to $8000 \mathrm{gm} / \mathrm{cc}^{*} \mathrm{~m} / \mathrm{sec}$.

The analysis of cross-plots between gamma ray versus density, gamma ray versus resistivity, gamma ray versus P-wave velocity, gamma ray versus P-wave impedance and gamma ray versus neutron porosity for depth interval of 249.95 to $1344.45 \mathrm{~m}$ for well J3 and similar crossplots for depth intervals of 249.94 to $1372.24 \mathrm{~m}$ in well J4 manifests the lithology like coal, shaly coal, shaly sandstone/shaly sand and sandstone/sand. Some coal seams are found to be heat affected. When igneous intrusive come into contact with a coal seam, coal is heated up and appeared as if baked or become low volatile coal. The completely baked devolatalised coal is called jhama. In these two wells (J3 and J4) jhama is found with coal.

The cross-plots between the gamma ray and density for wells J2, S1, S10, S14, K4, K10 and M1 have been displayed for depth interval $249.96 \mathrm{~m}$ to $1183.81 \mathrm{~m}$, $499.98 \mathrm{~m}$ to $902.08 \mathrm{~m}, 519.97 \mathrm{~m}$ to $1220.67 \mathrm{~m}, 539.97 \mathrm{~m}$ to $786.02 \mathrm{~m}, 140.98 \mathrm{~m}$ to $849.78 \mathrm{~m}, 240.97 \mathrm{~m}$ to 903.67 $\mathrm{m}$ and $200.02 \mathrm{~m}$ to $1081.92 \mathrm{~m}$ respectively (Figure 3(a), Figure 3(b), Figure 3(d), Figure 3(e), Figure 4(a), Figure 4(c) and Figure 4(d) respectively). Density versus resistivity cross-plots are also shown for wells S1 and K4 in Figures 3(c) and 4(b) respectively. Resistivity versus gamma ray cross-plots for wells J1, J3, J4, S1 and K4 could not able to identify carbonaceous shale/ shale and shaly coal. It was difficult to identify coal and igneous intrusions from the resistivity versus gamma ray crossplots.

For most of these wells it was easy to identify the coal, shaly coal, carbonaceous shale, shale, shaly sand and sand from the density versus gamma ray cross-plots. The high density values ranging from $2.8 \mathrm{gm} / \mathrm{cc}$ to $3.2 \mathrm{gm} / \mathrm{cc}$ and gamma ray value ranging from $50 \mathrm{cps}$ to $280 \mathrm{cps}$ have been observed in these wells. This may be due to the igneous intrusions in this area.

The density, gamma ray and resistivity values in coal for these wells (J2, S1, S10, S14, K4, K10 and M1) varies from $1.28 \mathrm{gm} / \mathrm{cc}$ to $1.55 \mathrm{gm} / \mathrm{cc}, 20 \mathrm{cps}$ to $50 \mathrm{cps}$ and $500 \mathrm{ohm}-\mathrm{m}$ to $1200 \mathrm{ohm}-\mathrm{m}$; in alternation of coal and shaly coal from $1.4 \mathrm{gm} / \mathrm{cc}$ to $2.0 \mathrm{gm} / \mathrm{cc}, 100 \mathrm{cps}$ to 150 cps and $100 \mathrm{ohm}-\mathrm{m}$ to $500 \mathrm{ohm}-\mathrm{m}$; in carbonaceous 


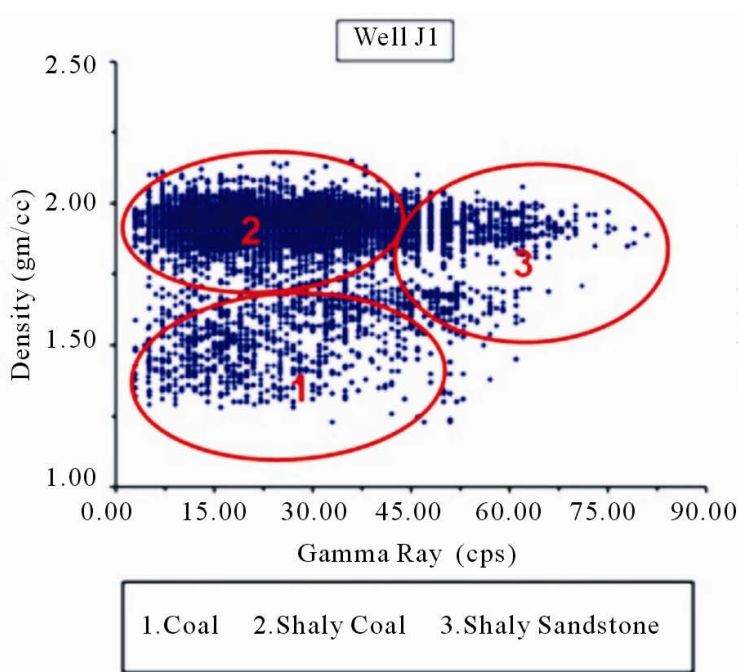

(a)

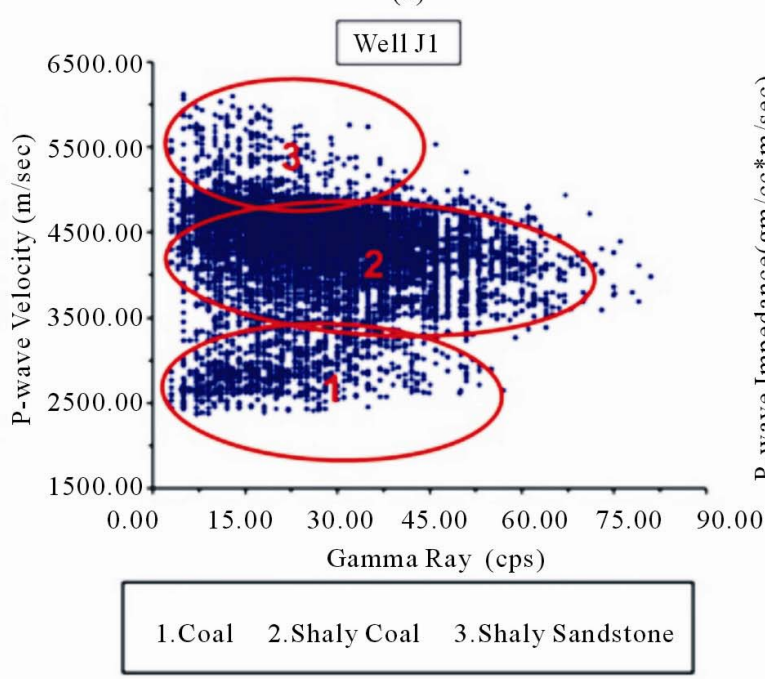

(c)

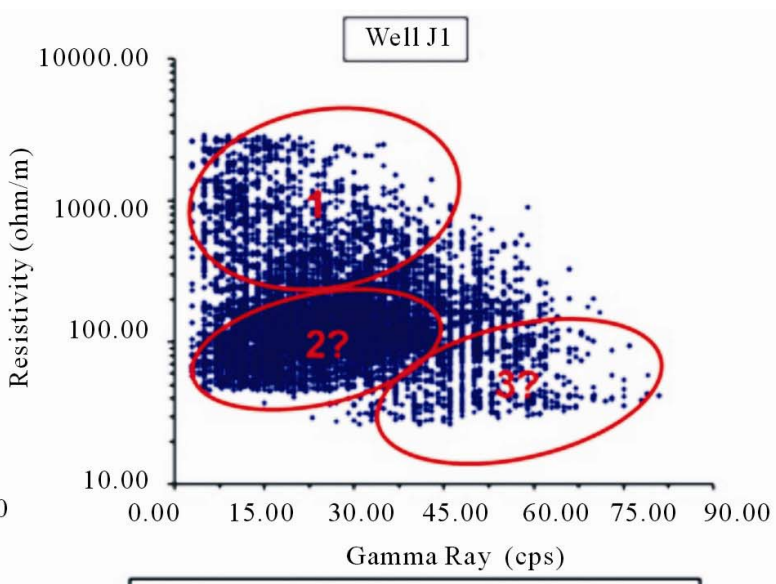

1.Coal 2.Shaly Coal 3.Shaly Sandstone

(b)

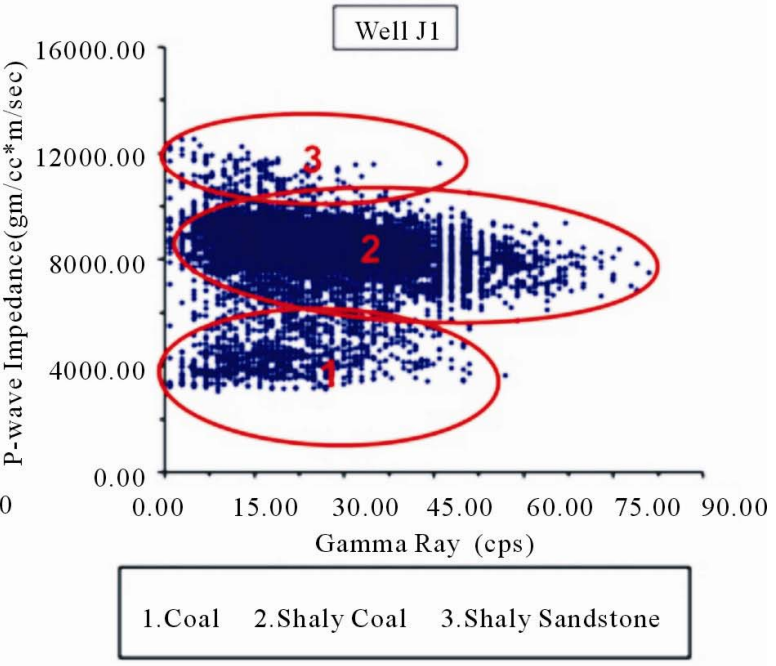

(d)

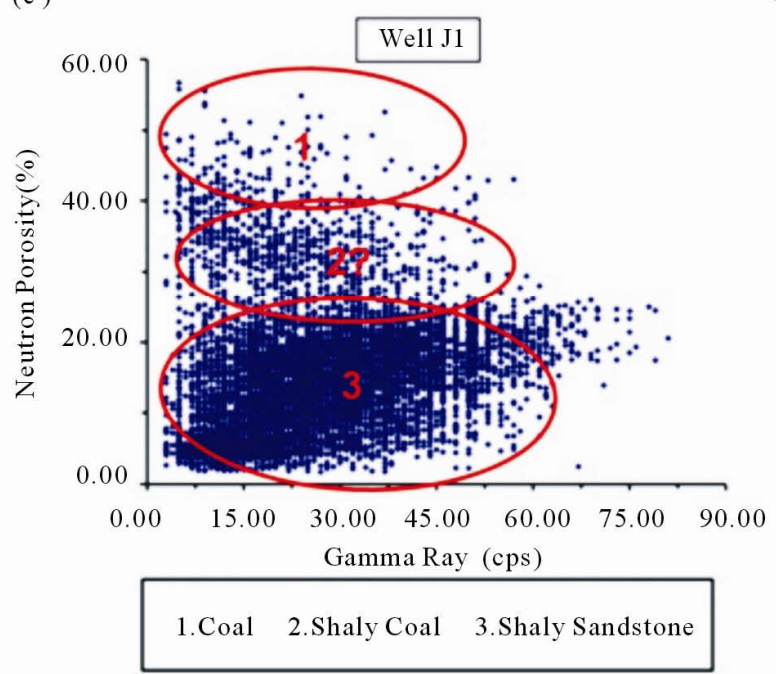

(e)

Figure 2. Identification of litho-units from (a) Gamma ray versus density; (b) Gamma ray versus resistivity; (c) Gamma ray versus P-wave velocity; (d) Gamma ray versus P-wave impedance and (e) Gamma ray versus neutron porosity cross-plots for well $\mathbf{J 1}$ of Jharia coalfield, India. 

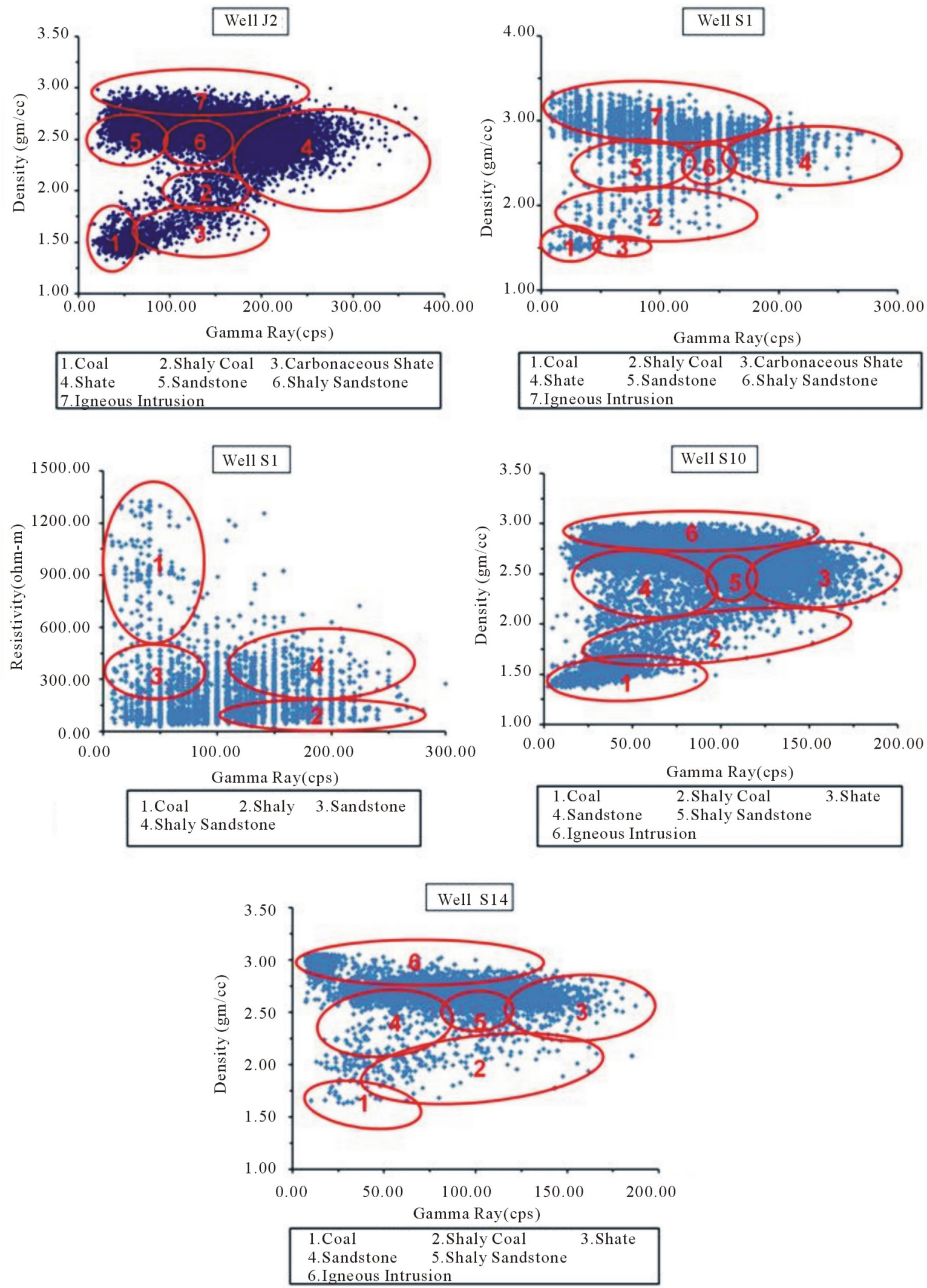

Figure 3. Identification of litho-units from (a) Gamma ray versus density cross-plot for well J2; (b) Gamma ray versus density and (c) Gamma ray versus resistivity cross-plots for well S1; (d) Gamma ray versus density cross-plot for well S10 and (e) Gamma ray versus density cross-plot for well S14 of Jharia coalfield, India. 


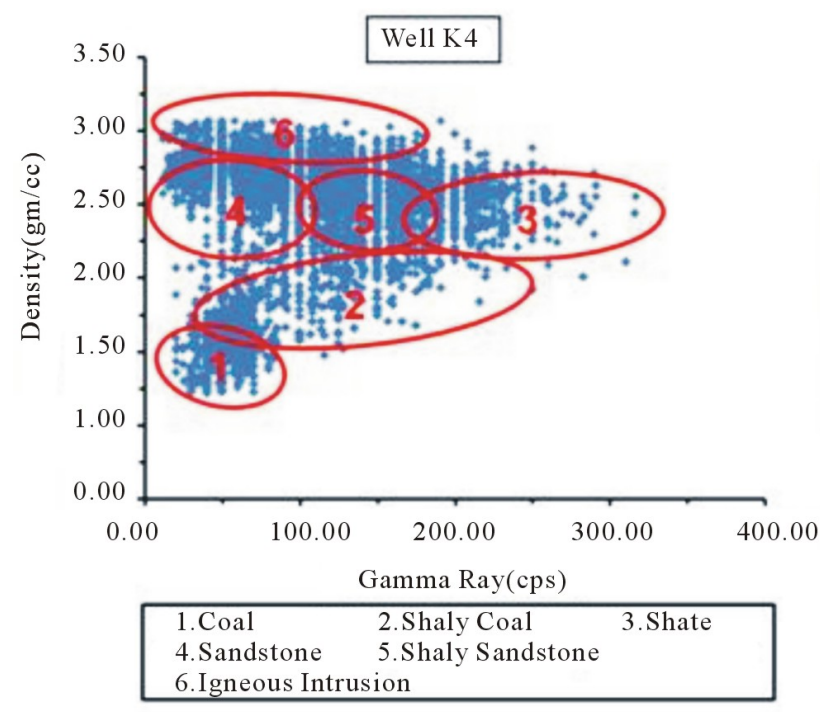

(a)

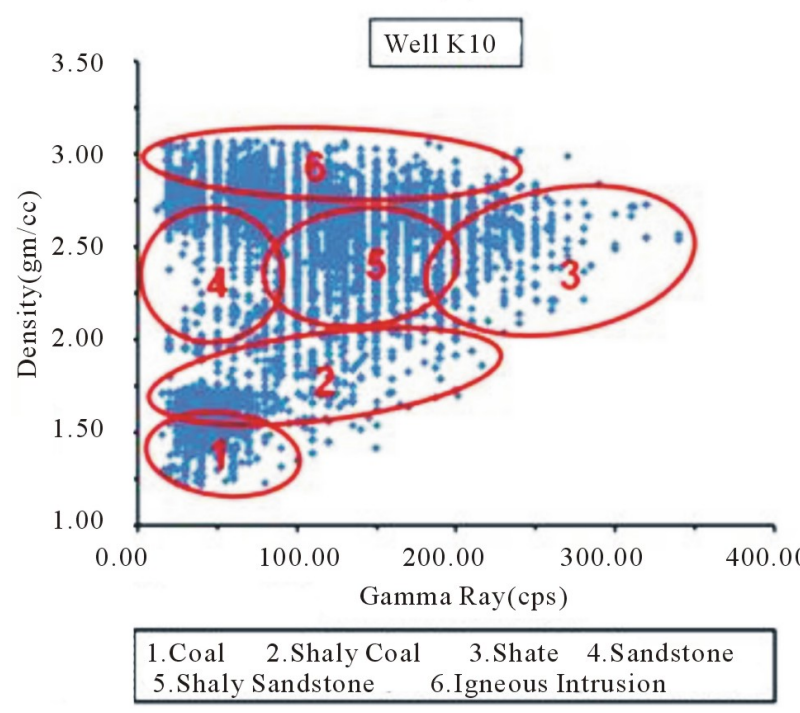

(c)

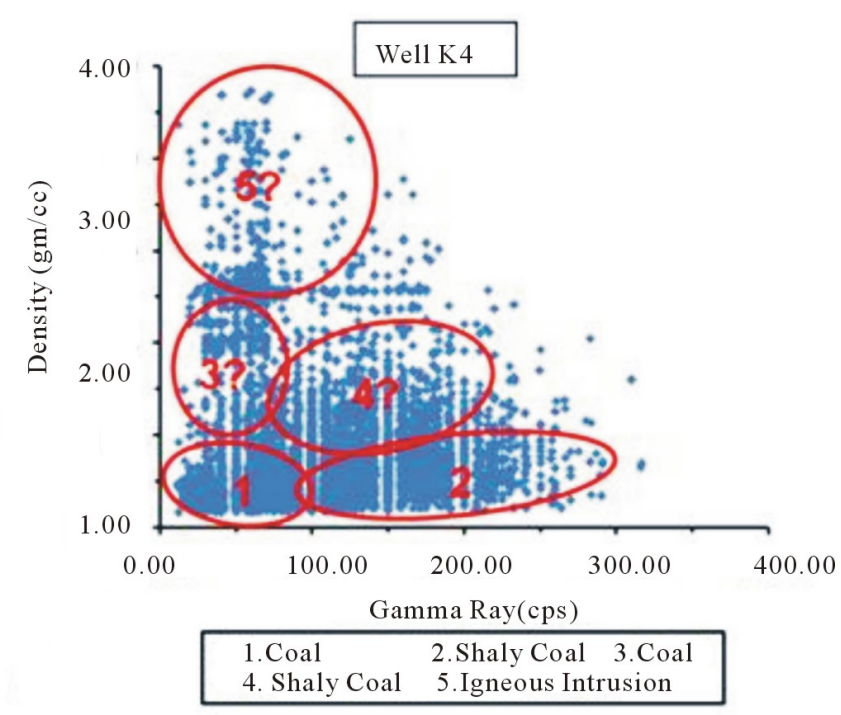

(b)

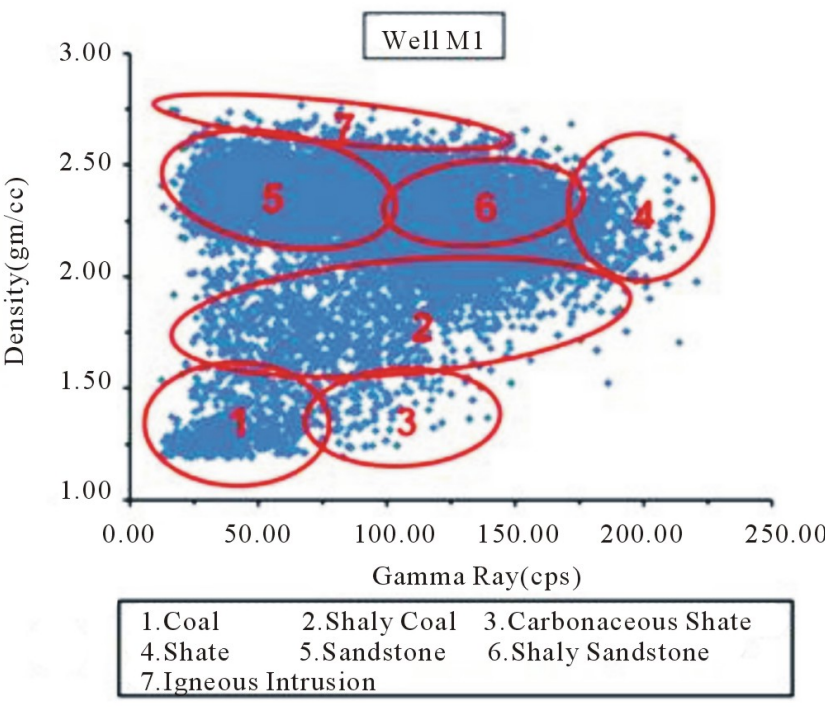

(d)

Figure 4. Identification of litho-units from (a) Gamma ray versus density and (b) Gamma ray versus resistivity cross-plots for well K4; (c) Gamma ray versus density cross-plot for well K10 and (d) Gamma ray versus density cross-plot for well M1 of Jharia coalfield, India

Table 2. Well log derived physical parameters for coal bearing litho-units of Jharia coalfield, India.

\begin{tabular}{ccccccc}
\hline Litho-unit & $\begin{array}{c}\text { Gamma Ray Log } \\
\text { (cps) }\end{array}$ & $\begin{array}{c}\text { Density Log } \\
\text { (gm/cc) }\end{array}$ & $\begin{array}{c}\text { Resistivity Log } \\
\mathbf{( 0 h m - m )}\end{array}$ & $\begin{array}{c}\text { Neutron Porosity Log } \\
\mathbf{( \% )}\end{array}$ & $\begin{array}{c}\text { P-wave Velocity } \\
\text { (m/sec) }\end{array}$ & $\begin{array}{c}\text { P-wave Impedance } \\
\text { (gm/cc*m/sec) }\end{array}$ \\
\hline Coal & $20-70$ & $1.32-1.60$ & $500-4000$ & $55-80$ & $2200-3000$ & $3000-4500$ \\
Shaly Coal & $70-90$ & $1.60-1.90$ & $400-800$ & $40-50$ & $3000-4500$ & $4500-10000$ \\
Carb. Shale & $90-180$ & $1.45-1.60$ & $250-400$ & $30-50$ & $3200-4500$ & $4800-10000$ \\
Shale & $90-280$ & $2.00-2.55$ & $1-15$ & $20-40$ & $3000-5000$ & $4500-11000$ \\
Sandstone & $30-60$ & $1.95-2.72$ & $50-400$ & $10-25$ & $4000-5000$ & $7800-14000$ \\
Jhama & $20-50$ & $1.70-2.00$ & $20-60$ & $60-80$ & $2200-3000$ & $3500-4500$ \\
\hline
\end{tabular}

Carb. $=$ Carboneceous. 
shale from $1.48 \mathrm{gm} / \mathrm{cc}$ to $1.6 \mathrm{gm} / \mathrm{cc}, 100 \mathrm{cps}$ to $160 \mathrm{cps}$ and $250 \mathrm{ohm}-\mathrm{m}$ to $400 \mathrm{ohm}-\mathrm{m}$; in sand from $2.45 \mathrm{gm} / \mathrm{cc}$ to $2.62 \mathrm{gm} / \mathrm{cc}, 20 \mathrm{cps}$ to $80 \mathrm{cps}$ and $10 \mathrm{ohm}-\mathrm{m}$ to 100 ohm-m; in shaly sand from $2.3 \mathrm{gm} / \mathrm{cc}$ to $2.4 \mathrm{gm} / \mathrm{cc}, 80$ cps to $150 \mathrm{cps}$ and $50 \mathrm{ohm}-\mathrm{m}$ to $80 \mathrm{ohm}-\mathrm{m}$ and in shale from $2.0 \mathrm{gm} / \mathrm{cc}$ to $2.44 \mathrm{gm} / \mathrm{cc}, 150 \mathrm{cps}$ to $300 \mathrm{cps}$ and 1 ohm-m to $10 \mathrm{ohm}-\mathrm{m}$ respectively. It is observed that shaly coal and shaly sandstone may not be identified from the lone gamma ray versus resistivity cross-plot.

\section{Identification of Coal Seams from Well Logs}

All the coal seams of 15 exploratory wells, namely, S1, S5, S8, S10, S14, K1, K4, K8, K1, J1, J2, J3, J4, M1 and M2 have been identified from combined signatures of available gamma ray, resistivity and density logs against coal and non-coal litho-units whereas coal seams in well J5 are marked with the help of available litho-log.

The classification/nomenclature of identified coal seams have been carried out with the help of available litho-log data which were prepared considering the following factors: a) thickness of coal and non-coal lithounits; b) litho-units occurring at the roof and floor of the coal seams with trend of litho-facies variation etc. It is to be mentioned here that for nomenclature of coal seams, available litho-logs played the most important role.
Though all the major and local coal seams of the study area are identified but for this present study only major/regionally persistent coal seams are considered. A total of 18 major coal seams, namely, seams A, B, C, D, E, F, G, H, I, J, K, L, M, N, O, P, Q and R are identified where seam $A$ is the bottom most and seam $R$ is the top most seam.

The bottom most seam A is identified only in well S10 from well $\log$ analysis. Due to the presence of thin non-coal units/partings between seams $\mathrm{E}$ and $\mathrm{F}$ and seams $F$ and $G$ throughout the study area, the seams E, F and G are always marked as a single seam (E/F/G combined seam) for this study area. To show the major seams as identified from well logs, a selected depth interval from $140.98 \mathrm{~m}$ to $849.78 \mathrm{~m}$ for well K4 and from $519.97 \mathrm{~m}$ to $1220.77 \mathrm{~m}$ for well S10 is chosen out of the 15 wells. Figure 5 displays the signature of gamma ray, short normal resistivity and caliper corrected density log with identified major coal seams for wells K4 and Figure 6 displays the signature of gamma ray and caliper corrected density log for well S10.

Tables 3-6 include particulars of the well number, seam name, depth and thickness of regional coal seam. The major persistent coal seams may act as a potential CBM reservoir under the study area.
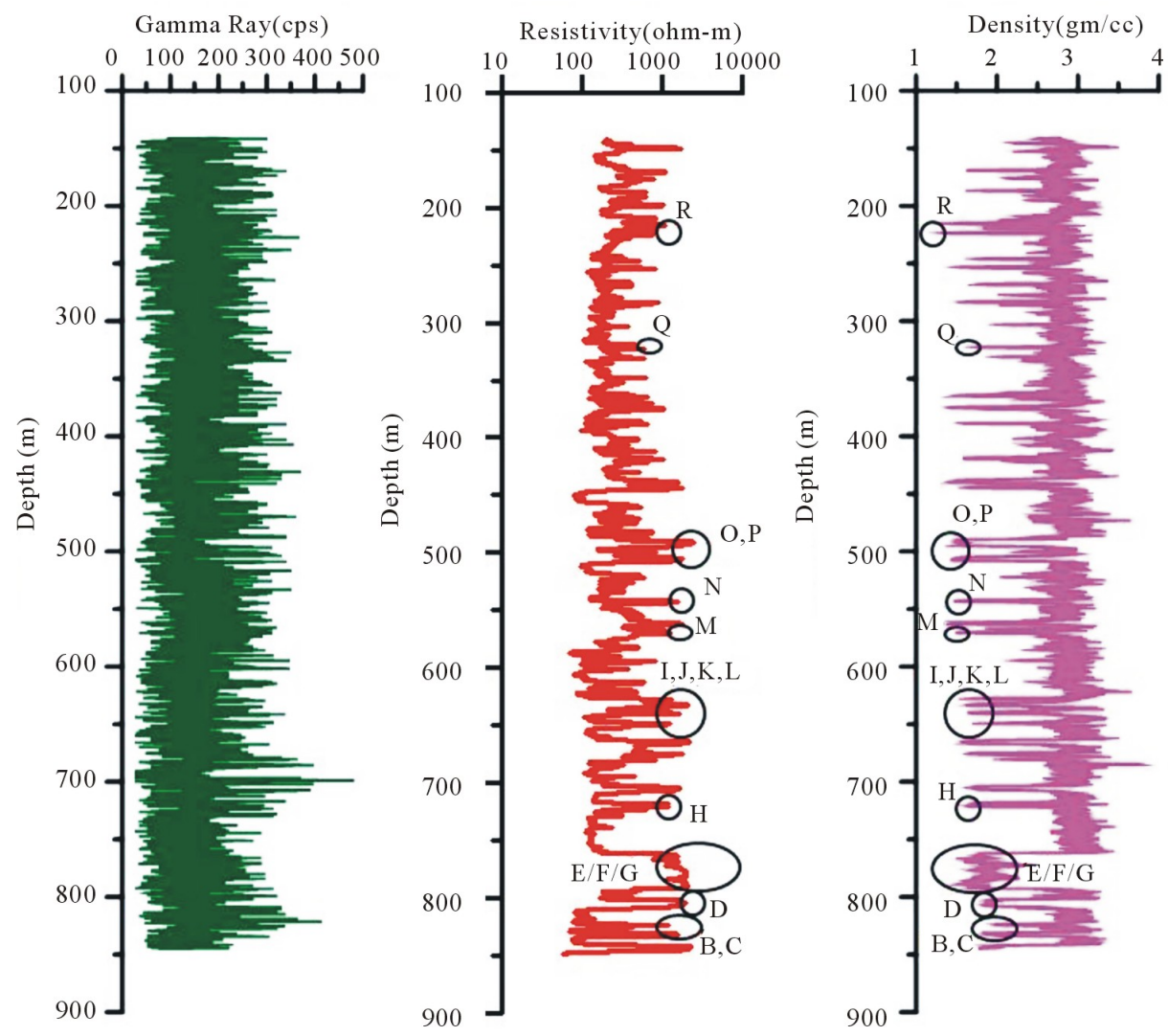

Figure 5. Identification of major coal seams for Well K4 of Jharia coalfield, India. 


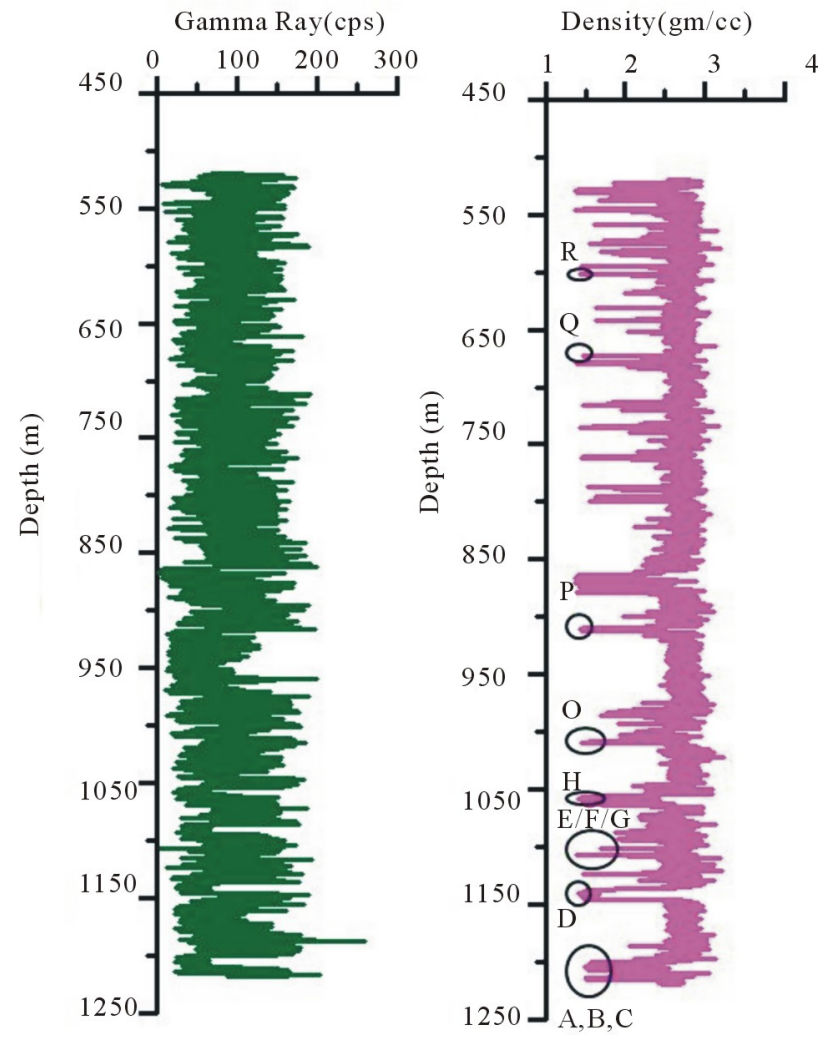

Figure 6. Identification of major coal seams for Well S10 of Jharia coalfield, India.

Table 3. Coal seam correlation data prepared from well log, coal core sample and litho-log analysis of 15 exploratory wells for seams R, Q, $P$ and $O$ in Jharia coalfield, India.

\begin{tabular}{|c|c|c|c|c|c|c|c|c|c|c|c|c|c|c|}
\hline \multirow{3}{*}{$\begin{array}{l}\text { Well } \\
\text { No. }\end{array}$} & \multirow{3}{*}{$\begin{array}{c}\text { Well } \\
\text { Name }\end{array}$} & \multirow{3}{*}{$\begin{array}{c}\text { Well } \\
\text { Collar } \\
\text { (m) }\end{array}$} & \multicolumn{3}{|c|}{ Seam $\mathbf{R}$} & \multicolumn{3}{|c|}{ Seam Q } & \multicolumn{3}{|c|}{ Seam $\mathbf{P}$} & \multicolumn{3}{|c|}{ Seam 0} \\
\hline & & & \multicolumn{2}{|c|}{ Depth (m) } & \multirow{2}{*}{$T(m)$} & \multicolumn{2}{|c|}{ Depth (m) } & \multirow{2}{*}{$T(m)$} & \multicolumn{2}{|c|}{ Depth (m) } & \multirow{2}{*}{$T(m)$} & \multicolumn{2}{|c|}{ Depth (m) } & \multirow{2}{*}{$T(\mathbf{m})$} \\
\hline & & & From & To & & From & To & & From & To & & From & To & \\
\hline 1 & S1 & 169.19 & 574.88 & 576.98 & 2.10 & 708.08 & 708.98 & 0.90 & \multicolumn{3}{|c|}{ WL NA } & \multicolumn{3}{|c|}{ WL NA } \\
\hline 2 & S5 & 163.31 & "796.07 & 797.17 & 1.10 & "837.47 & 838.77 & 1.30 & *1052.67 & 1057.27 & 4.60 & *1063.97 & 1069.47 & 5.50 \\
\hline 3 & S8 & 170.29 & 657.06 & 658.86 & 1.80 & 725.66 & 726.86 & 1.20 & 960.06 & 962.76 & 2.70 & & UI WL & \\
\hline 4 & S10 & 153.62 & 601.17 & 602.37 & 1.20 & 672.57 & 673.32 & 0.75 & 909.82 & 912.32 & 2.50 & 1007.47 & 1010.27 & 2.80 \\
\hline 5 & S14 & 166.24 & 598.82 & 600.67 & 1.85 & 619.77 & 620.87 & 1.10 & \multicolumn{3}{|c|}{ WL/LL NA } & \multicolumn{3}{|c|}{ WL/LL NA } \\
\hline 6 & K1 & 182.39 & & UI & & 570.73 & 571.13 & 0.40 & 765.43 & 770.33 & 4.90 & 777.13 & 781.83 & 4.70 \\
\hline 7 & K4 & 190.81 & 214.58 & 216.08 & 1.50 & 282.78 & 284.08 & 1.30 & 490.08 & 495.88 & 5.80 & 504.98 & 508.78 & 3.80 \\
\hline 8 & K8 & 181.66 & 224.72 & 225.72 & 1.00 & 334.22 & 335.22 & 1.00 & 491.92 & 497.52 & 5.60 & 506.92 & 510.52 & 3.60 \\
\hline 9 & K10 & 191.91 & & UI & & & UI & & 548.47 & 555.07 & 6.60 & 563.77 & 568.17 & 4.40 \\
\hline 10 & $\mathrm{~J} 1$ & 195.00 & & LL NA & & & LL NA & & & LL NA & & & LL NA & \\
\hline 11 & $\mathrm{~J} 2$ & 180.00 & & LL NA & & & LL NA & & & LL NA & & 697.06 & 700.06 & 3.00 \\
\hline 12 & J3 & 174.00 & & LL NA & & & LL NA & & & LL NA & & 1016.65 & 1021.35 & 4.70 \\
\hline 13 & $\mathrm{~J} 4$ & 165.00 & & LL NA & & & LL NA & & & LL NA & & 1117.04 & 1121.54 & 4.50 \\
\hline 14 & M1 & 173.95 & & LL NA & & 594.42 & 596.07 & 1.65 & 733.77 & 738.77 & 5.00 & 879.52 & 886.97 & 7.45 \\
\hline 15 & M2 & 181.48 & 532.67 & 534.92 & 2.25 & 588.32 & 590.07 & 1.75 & & LL NA & & 725.67 & 731.17 & 5.50 \\
\hline
\end{tabular}

No. $=$ Number; $\mathrm{T}=$ Thickness; $\mathrm{WL}=$ Well Log; $\mathrm{LL}=$ Litho Log; UI $=$ Unable to Identify from WL but seam is identified from LL; NA $=$ Not Available; ${ }^{*}=$ coal seam identified with the help of available coal core samples and LL data. 
Table 4. Coal seam correlation data prepared from well log, coal core sample and litho-log analysis of 15 exploratory wells for seams $N, M, L$ and $K$ in Jharia coalfield, India.

\begin{tabular}{|c|c|c|c|c|c|c|c|c|c|c|c|c|c|c|}
\hline \multirow{3}{*}{$\begin{array}{l}\text { Well } \\
\text { No. }\end{array}$} & \multirow{3}{*}{$\begin{array}{c}\text { Well } \\
\text { Name }\end{array}$} & \multirow{3}{*}{$\begin{array}{l}\text { Well } \\
\text { Collar } \\
\text { (m) }\end{array}$} & \multicolumn{3}{|c|}{ Seam $\mathbf{N}$} & \multicolumn{3}{|c|}{ Seam $\mathbf{M}$} & \multicolumn{3}{|c|}{ Seam L } & \multicolumn{3}{|c|}{ Seam K } \\
\hline & & & \multicolumn{2}{|c|}{ Depth (m) } & \multirow{2}{*}{$\mathrm{T}(\mathrm{m})$} & \multicolumn{2}{|c|}{ Depth (m) } & \multirow{2}{*}{$\mathbf{T}(\mathbf{m})$} & \multicolumn{2}{|c|}{ Depth (m) } & \multirow{2}{*}{$\begin{array}{c}T \\
(\mathbf{m})\end{array}$} & \multicolumn{2}{|c|}{ Depth (m) } & \multirow{2}{*}{$\begin{array}{c}T \\
(\mathbf{m})\end{array}$} \\
\hline & & & From & To & & From & To & & From & To & & From & To & \\
\hline 1 & S1 & 169.19 & \multicolumn{3}{|c|}{ WL NA } & \multicolumn{3}{|c|}{ WL NA } & \multicolumn{3}{|c|}{ WL NA } & \multicolumn{3}{|c|}{ WL NA } \\
\hline 2 & S5 & 163.31 & \multicolumn{3}{|c|}{ WL/CC/LL NA } & \multicolumn{3}{|c|}{ WL/CC/LL NA } & \multicolumn{3}{|c|}{ WL/CC/LL NA } & \multicolumn{3}{|c|}{ WL/CC/LL NA } \\
\hline 3 & S8 & 170.29 & 1019.46 & 1021.36 & 1.90 & 1043.96 & 1045.86 & 1.90 & 1098.46 & 1101.76 & 3.30 & 1102.86 & 1104.26 & 1.40 \\
\hline 4 & S10 & 153.62 & \multicolumn{3}{|c|}{ Fault } & \multicolumn{3}{|c|}{ Fault } & \multicolumn{3}{|c|}{ Fault } & \multicolumn{3}{|c|}{ Fault } \\
\hline 5 & S14 & 166.24 & \multicolumn{3}{|c|}{ WL/LL NA } & \multicolumn{3}{|c|}{ WL/LL NA } & \multicolumn{3}{|c|}{ WL/LL NA } & \multicolumn{3}{|c|}{ WL/LL NA } \\
\hline 6 & K1 & 182.39 & \multicolumn{3}{|c|}{ WL NA } & \multicolumn{3}{|c|}{ WL NA } & & WL NA & & & WL NA & \\
\hline 7 & K4 & 190.81 & 542.08 & 543.68 & 1.60 & 561.28 & 563.28 & 2.00 & 631.48 & 634.38 & 2.90 & 639.88 & 641.08 & 1.20 \\
\hline 8 & K8 & 181.66 & 540.92 & 542.22 & 1.30 & 562.52 & 564.32 & 1.80 & 633.72 & 636.02 & 2.30 & 643.22 & 644.82 & 1.60 \\
\hline 9 & K10 & 191.91 & 604.57 & 605.77 & 1.20 & 624.07 & 626.17 & 2.10 & 702.97 & 705.97 & 3.00 & 712.47 & 715.77 & 3.30 \\
\hline 10 & $\mathrm{~J} 1$ & 195.00 & & LL NA & & & LL NA & & & LL NA & & & LL NA & \\
\hline 11 & $\mathrm{~J} 2$ & 180.00 & & LL NA & & 791.26 & 794.96 & 3.70 & & LL NA & & & LL NA & \\
\hline 12 & J3 & 174.00 & & LL NA & & 1100.95 & 1108.75 & 7.80 & & LL NA & & & LL NA & \\
\hline 13 & $\mathrm{~J} 4$ & 165.00 & & LL NA & & & LL NA & & & LL NA & & & LL NA & \\
\hline 14 & M1 & 173.95 & & LL NA & & & LL NA & & & LL NA & & & LL NA & \\
\hline 15 & M2 & 181.48 & & LL NA & & & LL NA & & & LL NA & & & LL NA & \\
\hline
\end{tabular}

No. = Number; $\mathrm{T}=$ Thickness; $\mathrm{WL}=$ Well Log; $\mathrm{CC}=$ Coal Core LL = Litho Log; NA = Not Available; Fault = Fault marked in LL .

Table 5. Coal seam correlation data prepared from well log, coal core sample and litho-log analysis of 15 exploratory wells for seams $J, I, H$ and $E / F / G$ in Jharia coalfield, India.

\begin{tabular}{|c|c|c|c|c|c|c|c|c|c|c|c|c|c|c|}
\hline \multirow{3}{*}{$\begin{array}{l}\text { Well } \\
\text { No. }\end{array}$} & \multirow{3}{*}{$\begin{array}{c}\text { Well } \\
\text { Name }\end{array}$} & \multirow{3}{*}{$\begin{array}{c}\text { Well } \\
\text { Collar } \\
\text { (m) }\end{array}$} & \multicolumn{3}{|c|}{ Seam $\mathbf{J}$} & \multicolumn{3}{|c|}{ Seam I } & \multicolumn{3}{|c|}{ Seam H } & \multicolumn{3}{|c|}{ Seam E/F/G } \\
\hline & & & \multicolumn{2}{|c|}{ Depth (m) } & \multirow{2}{*}{$\mathbf{T}(\mathbf{m})$} & \multicolumn{2}{|c|}{ Depth (m) } & \multirow{2}{*}{$\mathrm{T}(\mathrm{m})$} & \multicolumn{2}{|c|}{ Depth (m) } & \multirow{2}{*}{$\mathbf{T}(\mathbf{m})$} & \multicolumn{2}{|c|}{ Depth (m) } & \multirow{2}{*}{$T(m)$} \\
\hline & & & From & To & & From & To & & From & To & & From & To & \\
\hline 1 & S1 & 169.19 & \multicolumn{3}{|c|}{ WL NA } & \multicolumn{3}{|c|}{ WL NA } & \multicolumn{3}{|c|}{ WL NA } & \multicolumn{3}{|c|}{ WL NA } \\
\hline 2 & S5 & 163.31 & \multicolumn{3}{|c|}{ WL/CC/LL NA } & \multicolumn{3}{|c|}{ WL/CC/LL NA } & \multicolumn{3}{|c|}{ WL/CC/LL NA } & \multicolumn{3}{|c|}{ WL/CC/LL NA } \\
\hline 3 & S8 & 170.29 & 1128.76 & 1130.46 & 1.70 & 1188.36 & 1195.96 & 7.60 & \multicolumn{3}{|c|}{ WL/LL NA } & \multicolumn{3}{|c|}{ WL/LL NA } \\
\hline 4 & S10 & 153.62 & & Fault & & & Fault & & 1054.87 & 1059.62 & 4.75 & 1086.97 & 1094.47 & 7.50 \\
\hline 5 & S14 & 166.24 & \multicolumn{3}{|c|}{ WL/LL NA } & \multicolumn{3}{|c|}{ WL/LL NA } & \multicolumn{3}{|c|}{ WL/LL NA } & \multicolumn{3}{|c|}{ WL/LL NA } \\
\hline 6 & K1 & 182.39 & \multicolumn{3}{|c|}{ WL NA } & \multicolumn{3}{|c|}{ WL NA } & \multicolumn{3}{|c|}{ WL NA } & \multicolumn{3}{|c|}{ WL NA } \\
\hline 7 & K4 & 190.81 & 663.78 & 667.28 & 3.50 & 674.88 & 676.38 & 1.50 & 720.58 & 721.58 & 1.00 & 762.08 & 792.68 & 30.60 \\
\hline 8 & K8 & 181.66 & & WL NA & & & WL NA & & & WL NA & & & WL NA & \\
\hline 9 & K10 & 191.91 & 735.47 & 738.07 & 2.60 & 746.47 & 748.07 & 1.60 & 788.07 & 790.77 & 2.70 & 831.17 & 860.17 & 29.00 \\
\hline 10 & $\mathrm{~J} 1$ & 195.00 & & LL NA & & & LL NA & & & LL NA & & 946.42 & 976.62 & 30.20 \\
\hline 11 & $\mathrm{~J} 2$ & 180.00 & 900.21 & 902.36 & 2.15 & & LL NA & & & LL NA & & & LL NA & \\
\hline 12 & J3 & 174.00 & 1223.75 & 1228.85 & 5.10 & 1244.05 & 1246.05 & 2.00 & 1327.05 & 1330.65 & 3.60 & & UI & \\
\hline 13 & $\mathrm{~J} 4$ & 165.00 & 1345.04 & 1354.24 & 9.20 & & LL NA & & & LL NA & & & LL NA & \\
\hline 14 & M1 & 173.95 & & LL NA & & & LL NA & & & LL NA & & & LL NA & \\
\hline 15 & M2 & 181.48 & & LL NA & & & LL NA & & & LL NA & & & LL NA & \\
\hline
\end{tabular}

No. $=$ Number; $\mathrm{T}=$ Thickness; $\mathrm{CC}=$ Coal Core; $\mathrm{WL}=$ Well Log; $\mathrm{LL}=$ Litho Log; $\mathrm{UI}=$ Unable to Identify from WL but seam is identified from LL; NA = Not Available; Fault = Fault marked in LL. 
Table 6. Coal seam correlation data prepared from well log, coal core sample and litho-log analysis of 15 exploratory wells for seams $D, C$, B and $A$ in Jharia coalfield, India.

\begin{tabular}{|c|c|c|c|c|c|c|c|c|c|c|c|c|c|c|}
\hline \multirow{3}{*}{$\begin{array}{l}\text { Well } \\
\text { No. }\end{array}$} & \multirow{3}{*}{$\begin{array}{c}\text { Well } \\
\text { Name }\end{array}$} & \multirow{3}{*}{$\begin{array}{l}\text { Well } \\
\text { Collar } \\
\text { (m) }\end{array}$} & \multicolumn{3}{|c|}{ Seam D } & \multicolumn{3}{|c|}{ Seam C } & \multicolumn{3}{|c|}{ Seam B } & \multicolumn{3}{|c|}{ Seam A } \\
\hline & & & \multicolumn{2}{|c|}{ Depth (m) } & \multirow{2}{*}{$T(m)$} & \multicolumn{2}{|c|}{ Depth (m) } & \multirow{2}{*}{$T(m)$} & \multicolumn{2}{|c|}{ Depth (m) } & \multirow{2}{*}{$\mathrm{T}(\mathrm{m})$} & \multicolumn{2}{|c|}{ Depth (m) } & \multirow{2}{*}{$\mathbf{T}(\mathbf{m})$} \\
\hline & & & From & To & & From & To & & From & To & & From & To & \\
\hline 1 & S1 & 169.19 & \multicolumn{3}{|c|}{ WL NA } & \multicolumn{3}{|c|}{ WL NA } & \multicolumn{3}{|c|}{ WL NA } & \multicolumn{3}{|c|}{ WL NA } \\
\hline 2 & S5 & 163.31 & \multicolumn{3}{|c|}{ WL/CC/LL NA } & \multicolumn{3}{|c|}{ WL/CC/LL NA } & \multicolumn{3}{|c|}{ WL/CC/LL NA } & \multicolumn{3}{|c|}{ WL/CC/LL NA } \\
\hline 3 & S8 & 170.30 & \multicolumn{3}{|c|}{ WL/LL NA } & \multicolumn{3}{|c|}{ WL/LL NA } & \multicolumn{3}{|c|}{ WL/LL NA } & \multicolumn{3}{|c|}{ WL/LL NA } \\
\hline 4 & S10 & 153.62 & 1137.17 & 1146.17 & 9.00 & 1185.22 & 1186.97 & 1.75 & 1200.77 & 1210.12 & 9.35 & 1214.52 & 1215.72 & 1.20 \\
\hline 5 & S14 & 166.24 & \multicolumn{3}{|c|}{ WL/LL NA } & \multicolumn{3}{|c|}{ WL/LL NA } & \multicolumn{3}{|c|}{ WL/LL NA } & \multicolumn{3}{|c|}{ WL/LL NA } \\
\hline 6 & K1 & 182.39 & \multicolumn{3}{|c|}{ WL NA } & \multicolumn{3}{|c|}{ WL NA } & & WL NA & & & WL NA & \\
\hline 7 & K4 & 190.81 & 802.28 & 808.08 & 5.80 & 831.18 & 833.48 & 2.30 & 842.28 & 846.38 & 4.10 & & WL NA & \\
\hline 8 & K8 & 181.66 & & WL NA & & & WL NA & & & WL NA & & & WL NA & \\
\hline 9 & K10 & 191.91 & 865.35 & 869.37 & 4.02 & 884.77 & 888.57 & 3.80 & "895.67 & 896.27 & 0.60 & & /CC/LL NA & \\
\hline 10 & $\mathrm{~J} 1$ & 195.00 & & LL NA & & & LL NA & & & LL NA & & & LL NA & \\
\hline 11 & $\mathrm{~J} 2$ & 180.00 & & LL NA & & & LL NA & & & LL NA & & & LL NA & \\
\hline 12 & J3 & 174.00 & & LL NA & & & LL NA & & & LL NA & & & LL NA & \\
\hline 13 & $\mathrm{~J} 4$ & 165.00 & & LL NA & & & LL NA & & & LL NA & & & LL NA & \\
\hline 14 & M1 & 173.95 & & LL NA & & & LL NA & & & LL NA & & & LL NA & \\
\hline 15 & M2 & 181.48 & & LL NA & & & LL NA & & & LL NA & & & LL NA & \\
\hline
\end{tabular}

No. = Number; $\mathrm{T}=$ Thickness; CC $=$ Coal Core; $\mathrm{WL}=$ Well Log; $\mathrm{LL}=$ Litho Log; NA = Not Available; Fault $=$ Fault marked in LL; ${ }^{*}=$ coal seam identified with the help of available CC samples and LL data.

\section{Conclusion}

The cross-plots such as gamma ray versus density, gamma ray versus $\mathrm{P}$-wave velocity and gamma ray versus $\mathrm{P}$-wave impedance show intersecting linear trends of coal and non-coal lithologies. Coal and sand litho-units are in two straight lines merging against shale. Clustering of points for different lithologies in the above cross-plots indicate that the different trends with marginal overlap between carbonaceous shale/shaly coal and shale as well as shaly sand and shale. These cross-plots clearly demonstrate that position of shale or sand on the cross-plot depends on sand: shale ratio of the given litho-unit. Hence sand-shale lithologies show distinctly different trend with respect to carbonaceous lithology. Gamma ray versus density cross-plots identifies coal, shaly coal, carbonaceous shale, sand, shay sand and shale. It may be further noticed that coal, shaly coal/shale and sands are very well identified in gamma ray versus P-wave velocity cross-plot. The combination of density and P-wave velocity in gamma ray versus $\mathrm{P}$-wave impedance cross-plots have been utilized for delineating coal and non-coal lithology. Pwave impedance for coal varies from $3000 \mathrm{gm} / \mathrm{cc}^{*} \mathrm{~m} / \mathrm{sec}$ to $4500 \mathrm{gm} / \mathrm{cc}^{*} \mathrm{~m} / \mathrm{sec}$ whereas P-wave impedance for sand varies from $9000 \mathrm{gm} / \mathrm{cc}^{*} \mathrm{~m} / \mathrm{sec}$ to $12000 \mathrm{gm} / \mathrm{cc}^{*} \mathrm{~m} /$ sec. Gamma ray versus neutron porosity cross-plots in wells $\mathrm{J} 3$ and J4 identify sand and coal clearly because neutron porosity response against coal is more due to maximum hydrogen richness index in coal and comparatively less hydrogen richness index in sand. The coal horizons are mostly overlain and underlain by shale or sandstone. Cross-plot analysis indicates the various coal lithologies which will play important role in CBM exploration and exploitation strategy.

\section{Acknowledgements}

The authors express their sincere gratitude to Coal India Limited (CIL) and Central Mine Planning and Design Institute Limited (CMPDIL), Ranchi for the financial assistance under its R\&D scheme. Supports extended by Mr. A. K. Singh, CMPDI Ranchi; Mr. A. N. Sahay, Director (RD\&T), CMPDI Ranchi; Chief General Manager (Exploration), CMPDI Ranchi; Mr. P. K. Hazra, General Manager (Geophysics), CMPDI Ranchi are gratefully acknowledged. Authors are thankful to Sri P. K. Pal, Ex-CGM (Exploration), CMPDI Ranchi for his kind support in editing the manuscript. 


\section{REFERENCES}

[1] W. B. Ayers Jr., "Coalbed Gas Systems, Resources, and Production and a Review of Contrasting Cases from the San Juan and Powder River Basins,” AAPG Bulletin, Vol. 86, No. 11, 2002, pp. 1853-1890.

[2] S. Bachu and K. Michael, "Possible Controls of Hydrogeological and Stress Regimes on the Producibility of Coalbed Methane in Upper Cretaceous-Tertiary Strata of the Alberta Basin, Canada,” AAPG Bulletin, Vol. 87, No. 11, 2003, pp. 1729-1754. doi:10.1306/06030302015

[3] J. S. Bell and S. Bachu, "In Situ Stress Magnitude and Orientation Estimates for Cretaceous Coal-Bearing Strata Beneath the Plains Area of Central and Southern Alberta," Bulletin of Canadian Petroleum Geology, Vol. 51, No. 1, 2003, pp. 1-28. doi:10.2113/gscpgbull.51.1.1

[4] T. Gentzis, "Review of Mannville Coal Geomechanical Properties: Application to Coalbed Methane Drilling in the Central Alberta Plains, Canada," Energy Sources, Part A: Recovery, Utilization, and Environmental Effects, Vol. 32, No. 4, 2009, pp. 355-369. doi:10.1080/15567030802466110

[5] H. E. Ross and M. D. Zoback, "Sub-Hydrostatic Pore Pressure in Coalbed and Sand Aquifers of the Powder River Basin, Wyoming and Montana, and Implications for Disposal of Coalbed-Methane-Produced Water through Injection,” Rocky Mountain Geology, Vol. 43, No. 2, 2008, pp. 155-169. doi:10.2113/gsrocky.43.2.155

[6] S. Hunze and T. Wonik, "Lithological and Structural Cha- racteristics of the Lake Bosumtwi Impact Crater, Ghana: Interpretation of Acoustic Televierwe Images," Meteoritics \& Planetary Science, Vol. 42, No. 4-5, 2007, pp. 779792. doi:10.1111/j.1945-5100.2007.tb01074.X

[7] M. G. Lamont, T. A. Thompson and C. Bevilacqua, "Drilling Success as a Result of Probabilistic Lithology and Fluid Prediction: A Case Study in the Carnarvon Basin, WA,” APPEA, 2008, pp. 1-12.

[8] P. F. Anderson and F. D. Gray, "Using LMR for Dual Attribute Lithology Identification,” Expanded Abstracts, SEG, San Antonio, 2001.

[9] F. D. Gray and E. C. Andersen, "Case Histories: Inversion for Rock Properties,” EAGE 62nd Conference and Technical Exposition, 2000.

[10] X. G. Chi and D. H. Han, "Lithology and Fluid Differentiation Using a Rock Physics Template," The Leading Edge, Vol. 28, No. 1, 2009, pp. 60-65. doi:10.1190/1.3064147

[11] L. M. Gochioco, "Recent Role of Geophysics in US Coal and CBM Development," The Leading Edge, Vol. 21, No. 5, 2002, pp. 452-455. doi:10.1190/1.1885502

[12] D. Chandra, “Jharia Coalfield,” Mineral Resources of India, Geological Society of India, Bangalore, 1992.

[13] Y. Yang, T. A. Cloud and C. W. Van Kirk, "New Applications of Well Log Parameters in Coalbed Methane (CBM) Reservoir Evaluation at the Drunkards Wash Unit, Uinta Basin, Utah,” SPE Eastern Regional Meeting, Morgantown, 14-16 September 2005, Paper ID: SPE 97988. 